\title{
Bacterial Contamination of Drinking Water in the Internally Displaced People Camps in South Darfur, Sudan
}

\author{
Yassir Mohammed Eltahir ${ }^{1^{*}}$, Amira Ahmed Abdelrahman ${ }^{2}$ \\ ${ }^{1}$ Department of Preventive Medicine and Veterinary Public Health, Faculty of Veterinary Science, Nyala University, Nyala Sudan \\ ${ }^{2}$ Department of Environmental Health Administration, State ministry of Health, South Darfur State, Nyala Sudan
}

Received 2013

\begin{abstract}
A total of 240 water samples were collected during the three seasons of 2009 from different sites and sources in the internally displaced camps (IDP) including bore holes, hand pumps, dug wells, water points, water reservoir and household storage containers. Samples were investigated using the most probable number method to detect and count the total coliform, faecal coliform and faecal enterococci. Enteric bacteria detected were E. coli, Enterococcus faecalis, Klebsiella, Citrobacter and Enterobacter .House hold containers showed continuous level of contamination by all different bacteria throughout the three seasons. This was followed by hand pumps, both reservoir and boreholes and dug wells. Water points revealed no level of contamination throughout the three seasons.
\end{abstract}

Keywords: Water Microbiology; Bacterial Contamination; E.coli

\section{Introduction}

The provision of drinking water of adequate quality and quantity remains a major public health need in many African countries, where diarrhoeal diseases continue to cause extensive morbidity and mortality [1]. In recent years, there has been a large movement of internally displaced people into the peripheral areas of Nyala city because of the civil war in Darfur region. These communities live in camps characterized by crowding, poor housing and inadequate water and sanitation.

The objective of this study was to investigate the prevalence of enteric bacteria contaminations in drinking water in South Darfur Sudan with special reference to the internally displaced people camps (IDPs).

\section{Methods}

Two hundred and forty water samples s were collected from the internally displaced camps (IDP) during the three seasons of 2009 from different sites and sources including bore holes, hand pumps, dug wells, water points, water reservoir and household storage containers. Camps included in the study were Otash, Derige, Kalma, Musay, Sacalee, Elsalam and Elserif camps located around Nyala city south Darfur, Sudan.

The Most Probable Number (MPN) of presumptive coliforms, faecal coliforms, and faecal streptococci (MPN/ $100 \mathrm{ml}$ water) using the Multiple Tube Fermentation Technique was used. Suspected colonies of coliform groups were further identified on the basis of morphological, cultural, and biochemical characteristics $[2,3]$

\section{Results}

Enteric bacteria isolated from water in total were E. coli (22.5\%), Enterococcus faecalis (20.42\%), Klebsiella (15\%), Citrobacter (2.1\%) and Enterobacter (3.33\%). In all seasons the most frequently $(4.58 \%)$ isolated bacteria from different sources was E.coli (Figure 1) and Enterococcus faecalis $(3.75 \%)$ with the highest contamination in house hold containers in autumn (Figure 2).

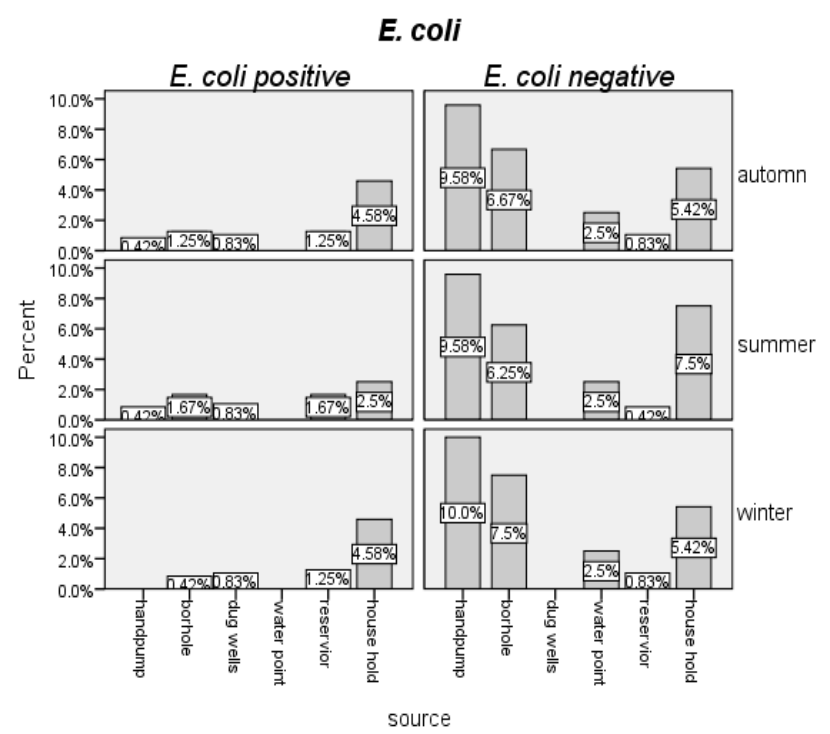

Figure 1. Contamination of drinking water by E.coli. 
This was followed by Klebsiella with the highest contamination (3.33\%) in boreholes in autumn (Figure 3).

Low frequently isolated bacteria were Citrobacter and Enterobacter that showed steady frequencies of $(0.42 \%$ and $0.83 \%$ ) in house hold containers in autumn and summer respectively (Figures $4 \& 5$ ).

The highest contamination of water sources was observed in household storage containers $(20 \%)$ followed by boreholes $(11.25 \%)$, reservoirs $(6.24 \%)$, hand pumps $(5.42 \%)$ and dug wells $(2.49 \%)$. Contamination varied from season to season with the highest level in autumn $(18.33 \%)$ followed by winter $(13.75 \%)$ and summer $(13.32 \%)$ respectively.

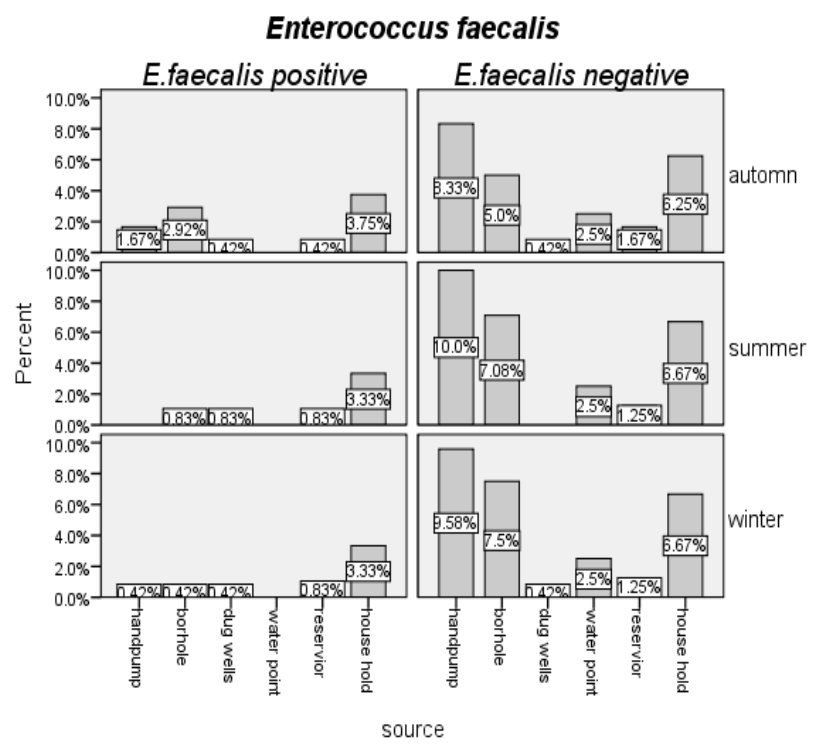

Figure 2. Contamination of drinking water by Enterococcus facialis.

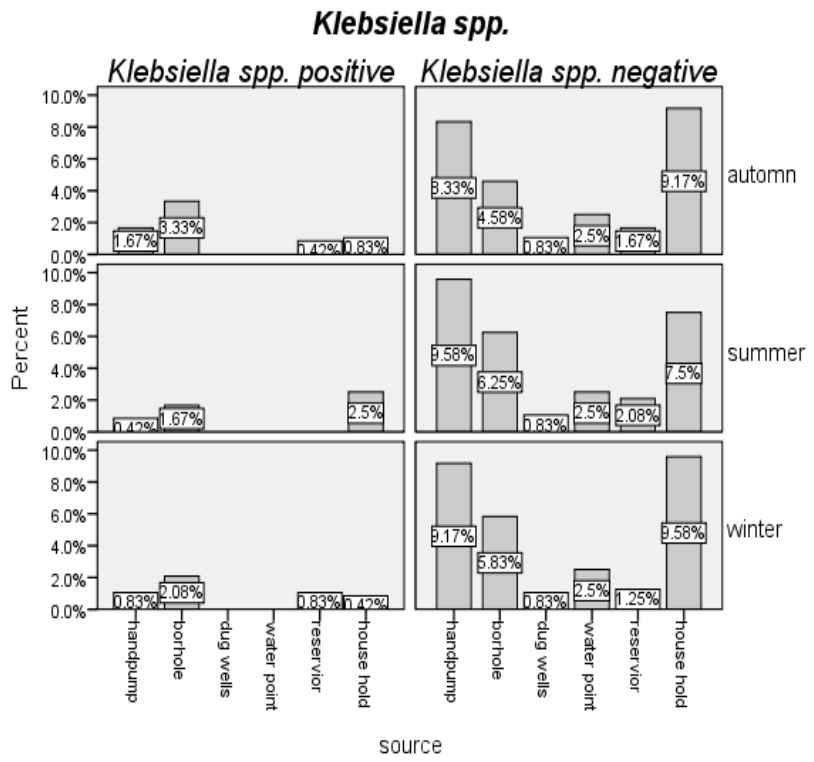

Figure 3. Contamination of drinking water by klebsiella.

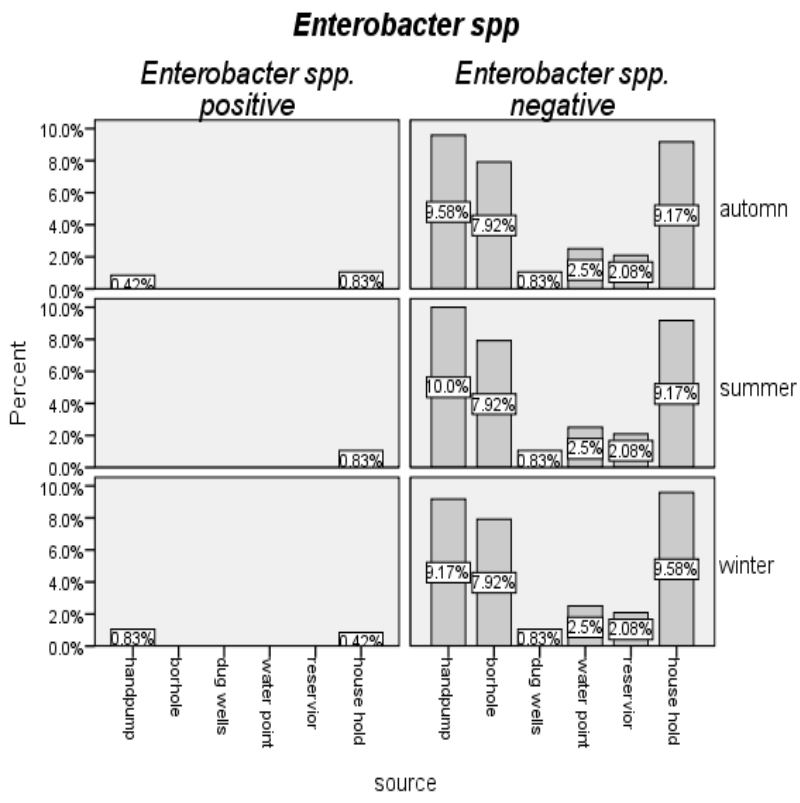

Figure 4. Contamination of drinking water by Enterobacter.

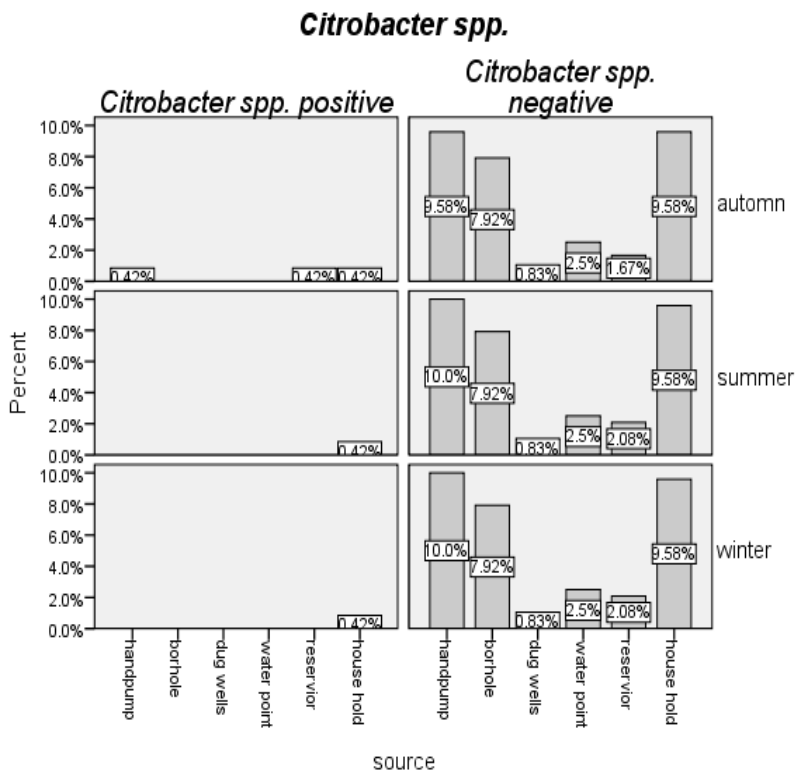

Figure 5. Contamination of drinking water by Citrobacter .

\section{Discussion}

All sources of water in IDP camps except water points were contaminated. The highest contamination in water sources was observed in household storage containers followed by reservoirs, boreholes, dug wells, and hand pumps. Contamination of water sources varied from season to season with the highest level in autumn followed by winter and summer. Data suggested the importance of greater attention for house hold contamination, environmental sanitation control and the raise of awareness about water contamination. 


\section{REFERENCES}

[1] A. G. Duse, M. P. Silva and I. Zietsman, "Coping with Hygiene in South Africa, A Water Scarce Country," International Journal of Environmental Health Research, Vol. 13, Supplement 001, 2003, pp. 95-105. doi:10.1080/0960312031000102859

[2] APHA. American Public Health Association, "Standard Methods for Examination of Water and Wastewater," 20th Edition, Washington, DC, USA, 1998.

[3] M. Stevens, N. Ashbolt and D. Cunliffe, Eds., "Review of Coliforms as Microbial Indicators of Drinking Water Quality-Recommendations to Change the Use of Coliforms as Microbial Indicators of Drinking Water Quality," NHMRC, Biotext Pty Ltd, Canberra, Australia, 2003, pp. 1-42. 